\title{
Hope for collaboration - brain meets mind in the midwest
}

\section{St Louis, Missouri}

Has the time arrived when a synthesis may emerge between basic neurobiology and cognitive science? As the home of the Center for Cellular and Molecular Neurobiology as well as the McDonnell Center for Higher Brain Function, Washington University seems ideally suited to resolve the issue. But even within the two centres there are differing opinions about how soon, if ever, research on the mind and brain can come together under one epistemological roof.

For Gerald Fischbach, director of the molecular centre, the jury is still out on the issue, but he is clearly not optimistic. Fischbach's centre consists of 15 faculty members working on the basic biology of the nervous system: how acetylcholine receptors are anchored to cell membranes, how acetylcholine receptor proliferation is induced at neuromuscular junctions, how cellular proteins are organized to form the cytoskeleton of growing nerve cells. As centre director, Fischbach is naturally enthusiastic about the progress of these efforts. But he has his doubts about how the molecular biologist can contribute to more global issues of brain function.

If there is one area that seems promising for collaboration, it is how molecularlevel studies might explain changes in neural wiring. It has recently become possible to study changes in the distribution of synapses on individual cells. Using living dyes, low light level video microscropy and digital image processing, Dale Purves and Jeffrey Lichtman are able to show changes in synapse distribution on peripheral ganglion neurons and neuromuscular junctions over six-month intervals. Extending this technique to neurons in the brain, accompanied by appropriate behaviour tasks, may provide a cellular model for studying behavioural plasticity.

Enthusiasm for collaboration is greater at the Center for Higher Brain Function, particularly in the laboratory of Marcus Raichle. Raichle has been using positron emission tomography (PET) to study cerebral blood flow. By injecting a bolus of water made with a radioactive isotope of oxygen with a 123-second half-life, Raichle has been able to take 40 -second 'snapshots' of deep brain blood flow. Collaborations with cognitive scientists Michael Posner and Steve Petersen have been fruitful, providing direct observation of brain areas active during processing of verbal information, confirming that the brain uses a parallel rather than a serial approach to processing lexical information (see Nature 331, 585; 1988).

Raichle says that by designing appro-

priate experiments it will be possible to find physiological correlates of complex psychological phenomena such as attention. Localizing brain areas involved in such processes will be the basis for more cellular and even molecular studies of brain function related to behaviour. It is not a question of whether tools of biology will be used by cognitive psychologists, says Raichle, but how those tools can be used.

Neuroscience at Washington University has benefited from the interest taken by the James S. McDonnell Foundation in issues regarding mind and brain. McDonnell, who died in 1980 , was the founder of the McDonnell Aircraft Company, now McDonnell-Douglas. But in addition to Washington University's centres, the foundation has decided to start an active search for programmes that will start off the next generation of brain

\section{South African institutes restructured}

\section{London}

South Africa's new Council for Scientific and Industrial Research (CSIR) will be officially commissioned on 1 April. The past nine months have seen a programme of rationalization in the largest of the three major research councils in order to cope with a reduction in state funding.

Impetus for the shake-up came after notice from the government that the state subsidy would be fixed at the 1986-87 figure of R234 million (see Nature 327, 275; 1987). The CSIR has responded by restructuring its 23 national research institutes into 11 technologically related divisions intended to attract increased contracts from both the private sector and government departments. Fundamental as opposed to applied research will no longer be undertaken by the council's laboratories, but will be the sole prerogative of the universities, funded by the Foundation for Research Development (FRD), the council's semi-autonomous wing, and serviced by the FRD's three national facilities: the South African Astronomical Observatory, the Radio Astronomy Observatory and the National Accelerator Centre.

The CSIR's president, Dr Chris Garbers, said recently that he was "aware that these extensive changes cannot be painless". Eight senior scientists (including two vicepresidents) in their sixties have been retired early, and a further six younger chief directors' posts have been cut. Of the 11 heads of the new research divisions, only one was appointed from outside the CSIR.

The stated aim of the restructuring is to use the country's (pitifully low) research and development funding as efficiently as research. Five panels, supported to the tune of $\$ 1.37$ million over two years, will bring together researchers studying perception, memory, attention, emotion and thought to explore whether a research agenda can be established for the field of 'cognitive neuroscience' or if indeed such a field can be said to exist.

Foundation president John Bruer believes the time may be right for pulling together normally disparate fields of neuroscience, developing an approach to asking more unified questions. Bruer says there has been an enthusiastic reception for a summer institute in cognitive neuroscience to be held in Boston this year.

But Bruer says his foundation is prepared to look elsewhere for the synthesis if after two years the panels say the time is not yet right. Fischbach sees the challenge of bringing the two centres at Washington University into greater collaboration as a bellwether for the success of future collaborations. "If it doesn't happen here", says Fischbach, "it isn't going to happen." Joseph Palca

possible - this constituted only 0.93 per cent of South Africa's gross national product in 1983-84, the last financial year for which figures are available. The government has made it quite clear that its contribution to research and development will not increase in the foreseeable future, so the CSIR has decided that its salvation lies in orientating itself towards applied research. Of private sector expenditure on research and development, 95 per cent is on 'inhouse' projects; only 2.7 per cent goes to universities, and the remaining 2.3 per cent to the research councils (1983-84 figures). In 1986-87, the CSIR earned R87 million (out of a budget of R321 million) from contract research. In the financial year now ending, this is expected to increase to R108 million, most from contracts from state departments. Both the CSIR and the universities seek to increase private-sector funding.

The FRD seems happy to assume responsibility for fundamental research in the hope that its funding will increase accordingly; if that happens, the universities stand to gain as a result of the CSIR's rationalization. In 1986-87 the FRD allocated R42 million to university research, increased to $\mathrm{R} 48$ million in the financial year now ending, just below the 16 per cent required to keep abreast of inflation. The FRD requires almost twice its present budget, however, to phase in research funding for all the evaluated researchers in the universities. How much the FRD's budget is to be increased to match its new-found status as custodian of fundamental research remains to be seen. Michael Cherry 